\title{
Books
}

\section{Recently Published Books}

Chris Fowler, Jan Harding and Daniela Hofmann (eds), The Oxford Handbook of Neolithic Europe

Published by: Oxford University Press. Series: Oxford Handbooks in Archaeology.

Year of Publication: 2015, ISBN: 9780199545841.

Hardback, 1200pp, with 197 illustrations, £125.00.

Yannis Hamilakis, Archaeology and the Senses: Human Experience, Memory, and Affect

Published by: Cambridge University Press.

Year of Publication: 2015, ISBN: 9780521545990.

Paperback, 270pp, with 26 b/w illustrations, $£ 19.99$.

Robert Hensey, First Light: The Origins of Newgrange

Published by: Oxbow Books. Series: Oxbow Insights in Archaeology.

Year of Publication: 2015, ISBN: 9781782979517.

Paperback, 210pp, with 33 b/w and 4 colour illustrations, £15.99.

John Hunter and Ann Woodward, Ritual in Early Bronze Age Grave Goods: An examination of ritual and dress equipment from Chalcolithic and Early Bronze Age Graves in England

Published by: Oxbow Books.

Year of Publication: 2015, ISBN: 9781782976943.

Hardback, 616pp with colour illustrations, includes CD, £80.00.

Paul E. Kinzer, Stargazing Basics: Getting Started with Recreational Astronomy

Published by: Cambridge University Press.

Year of Publication: 2015, ISBN: 9781107439405.

Paperback, 173pp, with $91 \mathrm{~b} / \mathrm{w}$ and 12 colour illustrations, £12.99.

Nicola Laneri (ed.), Defining the Sacred: Approaches to the Archaeology of Religion in the Near East

Published by: Oxbow Books.

Year of Publication: 2015, ISBN: 9781782976790.

Paperback, 200pp, b/w illustrations, $£ 38.00$. 
Timothy Pauketat (ed.), The Oxford Handbook of North American Archaeology

Published by: Oxford University Press.

Year of Publication: 2015, ISBN: 9780190241094.

Paperback, 704pp, with 178 illustrations, £32.99.

F. Pimenta, N. Ribeiro, F. Silva, N. Campion, A Joaquinito and L. Tirapicos (eds), SEAC 2011 Stars and Stones: Voyages in Archaeoastronomy and Cultural Astronomy: Proceedings of the SEAC 2011 conference

Published by: Archaeopress, BAR International Series S2720.

Year of publication: 2015, ISBN: 9781407313733.

Paperback, 340pp, b/w illustrations $£ 53.00$.

Tim Thompson (ed.), The Archaeology of Cremation: Burned Human Remains in Funerary Studies

Published by: Oxbow Books. Series: Studies in Funerary Archaeology.

Year of Publication: 2015, ISBN: 9781782978480.

Paperback, 256pp, with colour and b/w illustrations, $£ 38.00$.

\section{Forthcoming Books}

\section{Alan Barnard, Language in Prehistory}

Published by: Cambridge University Press. Series: Approaches to the Evolution of Language.

Year of Publication: 2015 (December), ISBN: 9781107692596.

Paperback, 210pp with 7 b/w illustrations, £16.99.

Ceri Houlbrook and Natalie Armitage, An Artifactual Investigation into Ritual Practices and Popular Beliefs

Year of Publication: 2015 (December), ISBN: 9781785700101.

Paperback, 152pp, with b/w illustrations, $£ 35.00$.

\section{Fabio Silva, Towards Skyscape Archaeology}

Published by: Oxbow Books. Series: Oxbow Insights in Archaeology.

Year of Publication: 2016, ISBN 9781782979555.

Paperback, 35 b/w illustrations, £15.99. 